\title{
The Acceptance and Profitability of Mixed Cropping with Legumes and Non-Legumes
}

\author{
Dissertation \\ to attain the doctoral degree (Dr. sc. agr.) \\ of the Faculty of Agricultural Sciences \\ Georg-August-Universität Göttingen

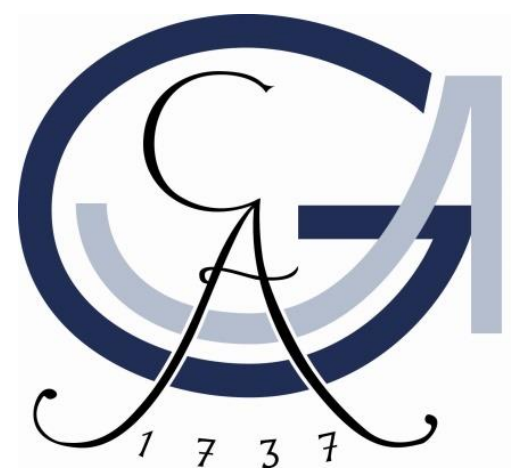

Submitted by

Vanessa Bonke

born on the 20.06.1989 in Paderborn

Göttingen, Feburary 2021 
1. Referee: Prof. Dr. Oliver Mußhoff

2. Referee: Prof. Dr. Achim Spiller

3. Referee: Prof. Dr. Jan-Henning Feil

Date of the oral examination: 30. April 2021 


\section{Table of Content}

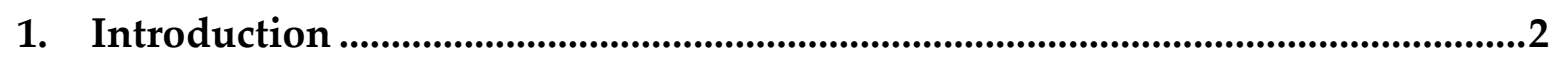

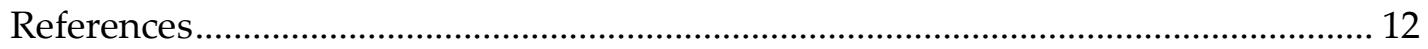

2. Understanding German Farmer's Intention to Adopt Mixed Cropping using the Theory of Planned Behavior .....................................................................................17

3. The Profitability of Mixed Cropping with Winter Faba Bean and Winter

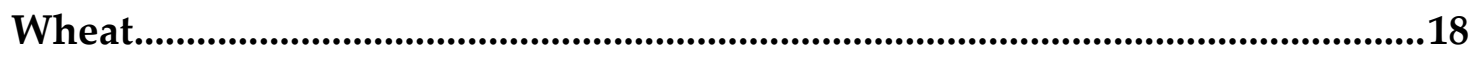

4. Will Farmers Accept Lower Gross Margins for the Sustainable Cultivation Method of Mixed Cropping?

5. Understanding the Adoption of Smartphone Apps in Crop Protection.........20

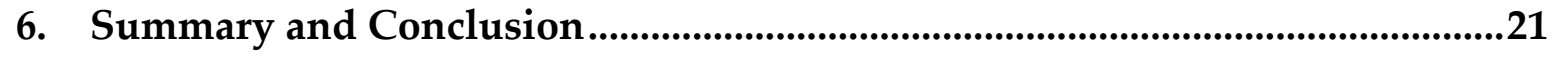

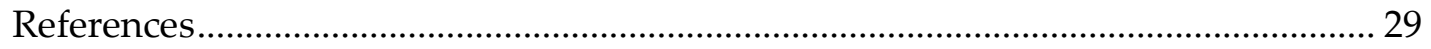

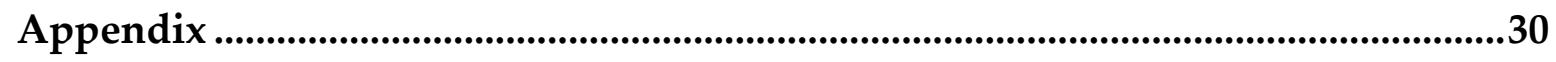

Publication List ........................................................................................................................ I

Declaration of Contribution ....................................................................................... IV

Eidesstattliche Erklärungen .................................................................................................... 


\section{Introduction}

The concept of sustainability has progressively gained relevance in modern agriculture and poses one its most fundamental challenges. There are multiple approaches possible towards an ecologically, economically and socially sustainable agriculture. Among the objectives outlined in the Sustainable Development Goals by the United Nations are the restoration of biodiversity and promotion of sustainable production patterns (United Nations 2015). Facilitating changes towards a more ecologically beneficial production and reducing negative environmental externalities are therefore at the forefront of the objectives the agricultural sector is striving towards (Melchior and Newig 2021). One approach to preserve and restore biodiversity within farming systems and contribute to a sustainable intensification is the diversification of cropping systems. Cropping systems can either be diversified over time by extending crop rotations or at the same time by applying mixed cropping.

Mixed cropping, or intercropping, is the simultaneous cultivation of two or more coexisting crops on the same area of land (Andrews and Kassam 1976). With respect to the arable production four main types of mixed cropping systems can be distinguished, in a descending order of contact between the cultivated species. The first type is the cultivation of mixed intercrops. In this form of cropping system, there is no specific arrangement of the plants involved within the mixed stand (Ofori and Stern 1987). This type of mixed cropping is relatively common for mixtures of catch crops or mixtures in green fodder production which are already common in the European agricultural sector (e.g., Bedoussac et al. 2015). Prominent examples are flowering strips or Landsberger mixtures (Hof and Rauber 2003). Sowing in alternating rows is another way to create a mixed stand (row intercropping). With this form of cultivation at least one species is sown in a row (Ofori and Stern 1987). Another form of mixed cropping is strip intercropping. The strip width can thereby be adapted to the working widths of machines which are available on the farm. However, the interactions between the two species are limited to the outer rows of the strips and thus complementary effects are correspondingly limited. The fourth type is relay intercropping, where the mixed stand exists only during a defined period of time in a specific development cycle of the species involved. An example for this type can 
be main crops with under sown grass or clover (Hof and Rauber 2003; Lithourgidis et al. 2011; Ofori and Stern 1987).

Mixed cropping with legumes and non-legumes in particular provides a number of benefits through the application of basic ecological concepts and the legumes unique ability to symbiotically fixate atmospheric nitrogen $(\mathrm{N})$ through associated bacteria in their root system. In addition to increasing biodiversity, mixed cropping, compared to sole cropping, promises an improved yield stability while reducing inputs of fertilizers and pesticides under low input conditions (Gaba et al. 2015; Hauggaard-Nielsen et al. 2008; Raseduzzaman and Jensen 2017). Mixed cropping can also help increase soil fertility, suppress weeds, and make better use of available resources, such as nutrients, water, and light (Chen et al. 2018; Jensen et al. 2020; Rodriguez et al. 2020; Wezel et al. 2014). These advantages of mixed stands only occur when the combined plant species use the available resources in a complementary manner and competitive effects do not dominate. The complementary use of nutrients of two or more species in mixed stands can partially be explained by differences in the temporal nutrient uptake and rooting characteristics of the involved species (Bedoussac and Justes 2010; Ergon et al. 2016).

However, this complementary, rather than competitive, use of growth factors only occurs if the species involved in mixed cropping have spatially and temporally different demands on their environment. To enable a better understanding of these socalled "mixing effects", the concept of competition must be further differentiated. The intraspecific competition describes the competition between plants of the same species for the available resources, whereas the interspecific competition describes the competition between plants of different species (Hof and Rauber 2003; Vandermeer 1992). For example, in a mixed stand with legumes and non-legumes, both the intraspecific competition among non-legumes and interspecific competition between legumes and non-legumes for the uptake of nitrogen is reduced (Jensen et al. 2020). This is inter alia based on the fact that, compared to pure stands, fewer non-legumes in a mixed stand compete with each other for the available soil $\mathrm{N}$, since a proportion of the plant population in the mixed stand has been replaced by the legumes. In addition, the interspecific competition for $\mathrm{N}$ is reduced in these mixed stands because the legumes meet most of their $\mathrm{N}$ needs through symbiotically fixated atmospheric $\mathrm{N}$. Thus, they make more soil $\mathrm{N}$ available to the non-legumes in the mixed stand. Furthermore, the uptake of $\mathrm{N}$ by the non-legumes leads to a lower 
availability of overall soil $\mathrm{N}$, which in turn again facilitates the atmospheric $\mathrm{N}$ fixation by the legumes in the mixed stand (Hauggaard-Nielsen et al. 2003; SiebrechtSchöll 2019). From this example, it is clear that interspecific competition and mutual facilitation are two simultaneous effects of the same interaction that can be observed in mixed cropping (Zhang and Li 2003). Overarching, these different effects are referred to as the "mixing effect". If this mixing effect is positive, a yield advantage of the mixed stand over the pure stand can be observed (also referred to as "overyielding"). The strength of these interaction effects between the involved plant species in the mixed stand is very closely related to its cultivation form or system. The more contact between the plant species, the greater both the competitive and complementary effects turn out to be (Hof and Rauber 2003).

The concept of mixing crop species is by no means new. The origins of crop mixtures can be traced back several thousand years ago to the domestication of arable crops in Mesoamerica. Among the most prominent examples of crop mixtures that were applied by the indigenous peoples are combinations of maize, bean, and pumpkin (Postma and Lynch 2012). In the global south, where smallholder farming is dominant and the availability of external inputs restricted, biodiversity based farming systems are still regularly applied (Labeyrie et al. 2021). In contrast, in the European Union (EU) the industrialization of agriculture caused a decline in the application of biodiversity based systems and mixed cropping practices over the past decades. The availability of mineral $\mathrm{N}$ fertilizers has also led to an overall decline in the cultivation of legumes, which has contributed to the biodiversity loss within agricultural production patterns (Mamine and Farès 2020; Meynard et al. 2018; Zander et al. 2016). Crop rotations are largely dominated by cereals nowadays: Around 121 Mio hectare (ha) of cereals were cultivated within the EU, whereas the cultivation of grain legumes only amounted to about 5 Mio ha in 2019 (FAOSTAT 2020). The crop production in Germany shows a similar structure with a high share of cereals and winter wheat being the most dominantly cultivated cereal by far (DESTATIS 2019). This has led to Germany being the second largest producer of wheat within the EU (EUROSTAT 2020a) but it has also contributed to Germany being the second largest consumer of mineral N fertilizers (EUROSTAT 2020b). Legumes have therefore gained increasing attention, both from politics and society. 2016 was declared as the international "year of pulses" by the UN. The market for legumes changes as new products emerge and consumer demands change. For instance, grain legume based pasta 
is already established as a protein rich alternative for wheat pasta, and regularly available in German supermarkets. The EU's Common Agricultural Policy (CAP) currently includes the cultivation of legumes as part of the greening restrictions, in order to encourage adoption by farmers. With the latest adaptations of the restrictions for Ecological Focus Areas (EFA) in 2018, Germany has now also included mixed stands with grain legumes and cereals into the regulations on the national level.

From todays' perspective, mixed cropping with legumes and cereals is an "innovative" possibility to increase the biodiversity within arable fields and (re)introduce more legumes into crop rotations. Combining cereals and legumes in mixed stands can in particular reduce the need for mineral $\mathrm{N}$ fertilizers which in turn decreases negative environmental effects, like greenhouse gas emissions that arise from the production of mineral fertilizers (Gellings and Parmenter 2016; Peoples et al. 2009). Mixed stands with cereals are also advantageous over pure legume stands, as nitrate leaching is decreased due to the uptake of $\mathrm{N}$ by the cereal (Jensen et al. 2020). However, the developments in the European agricultural sector over the past decades have led to a technological lock-in around the dominant cereal crops (Meynard et al. 2018). Introducing legumes into the production, as a sole crop but even more so in mixed stands, therefore poses many challenges for farmers and the need for research along different steps in the value chain has been emphasized multiple times (Jensen et al. 2020; Lemken et al. 2017; Mawois et al. 2019; Zimmer et al. 2016). For mixed cropping with grain legumes and cereals, as the combination of two main crops, several challenges have been highlighted. Starting with plant breeding, which has optimized and selected varieties in accordance with their performance in pure stands (Siebrecht-Schöll 2019), over technical challenges in sowing and harvest (Lemken et al. 2017), up to the processing of mixed yields which increases production costs (Mamine and Farès 2020). From the farmers perspective mixed cropping with main crops is consequently associated with a higher risk, not at least due to the fact that extensive operational knowledge for mixed stands is not readily available (Bedoussac et al. 2015). In addition, there is a persistent lack of research about the economic efficiency of mixed cropping with grain legumes and cereals (Lemken et al. 2017; Rosa-Schleich et al. 2019).

In consideration of the potential mixed cropping with grain legumes and cereals offers in contributing to a sustainable agriculture, the first three papers in this 
cumulative thesis address the topic of mixed cropping with cereals and grain legumes as main crops. These studies have been conducted as part of the multidisciplinary collaborative project IMPAC ${ }^{3}$ (Novel genotypes for mixed cropping allow for IMProved sustainable land use ACross arable land, grassland and woodland).

The first paper of this thesis titled "Understanding German Farmer's Intention to Adopt Mixed Cropping using the Theory of Planned Behavior" (published in Agronomy for Sustainable Development) aims to provide a profound understanding of psychological factors underlying famers behavior with respect to the adoption of mixed cropping (Chapter 2). It has been argued that the adoption of agri-environmental related measures and conservation practices is not solely dependent on financial motives (Lokhorst et al. 2011; Mills et al. 2017) and that behavioral insights are of particular relevance to help guide the development of voluntary agri-environmental policies (Dessart et al. 2019). Therefore, the paper utilizes a theory based in socio-psychological research that has already been applied in the context of different agri-environmental related measures (Greiner 2015; van Dijk et al. 2016). The Theory of Planned Behavior (TPB) which was developed by Ajzen $(1985,1991)$ postulates that human behavior is mainly driven by three central psychological constructs: The "Attitude towards the Behavior", the "Subjective Norm", and the "Perceived Behavioral Control". These constructs influence an individuals' "Intention to Perform a Behavior", which in turn is strong predictor for the actual "Behavior".

With respect to the adoption of mixed cropping with main crops in Germany, and the EU, there has only been one previous study by Lemken et al. (2017). The authors provided insights into the characteristics of early adopters of mixed cropping and found the farmers' attitude and technical barriers to statistically significantly influence the adoption decision. Following up on that and considering the challenges a farmer faces when introducing mixed cropping, understanding the decision-making process of farmers is paramount to facilitate the adoption of mixed cropping. Therefore, the objectives of this paper can be summarized as follows:

(1) Which and how do underlying psychological factors influence farmers' intention to adopt mixed cropping utilizing an extended TPB model?

(2) What adoption obstacles are perceived as most important by the farmers?

The paper utilizes an extended version of the TPB, using a sample of 172 German farmers. The model includes the additional constructs "Descriptive Group Norm", 
"Injunctive Group Norm", and "Perceived Ecological Benefits". The first part of model, up to the "Intention", was estimated with a Partial Least Squares Structural Equation Model (PLS-SEM) (Hair et al. 2017). The actual adoption decision, which is the "Behavior" in this application, was estimated with a logit model due to the binary data structure of the dependent variable. To answer the second research question, a ranking of the famers' responses about the obstacles they perceive as most important for the practical implementation of mixed cropping is provided. This ranking from the farmers' point of view offers additional insights, as these obstacles will need to be addressed by researchers in order to enhance the adoption.

Chapter 3 addresses the profitability of mixed cropping on a farm level basis. The Paper "The Profitability of Mixed Cropping with Winter Faba Bean and Winter Wheat" (published in: Berichte über Landwirtschaft-Zeitschrift für Landwirtschaft und Agrarpolitik) ${ }^{1}$ contributes to the limited literature about the economics of mixed cropping. The lack of research with respect to the profitability of different crop mixtures has been highlighted in the scientific literature (Rosa-Schleich et al. 2019) and was also ranked among the top obstacles from the German farmers' point of view (Chapter 2). In contrast to the pure stands, mixed stands with grain legumes and cereals are not included in any official statistics. Results with respect to the yields of mixed stands are mostly based on scientific field trials as there is no widespread practical application in the EU. Therefore, the following research questions are addressed:

(1) How profitable is the mixed cropping of winter wheat and winter faba bean applied in the IMPAC field experiments?

(2) How profitable would mixed cropping with winter wheat and winter faba bean have to be in order to be integrated into an economically optimized production program?

Based on the yield data from the IMPAC ${ }^{3}$ field experiments conducted at two different locations in Göttingen and over three years (2015-2017), a total of 960 individual gross margins were calculated for eight winter faba bean genotypes and three winter wheat varieties in mixed and pure stands. To evaluate the so called "mixing effect" the relative gross margins of mixtures were calculated. A whole-farm model that

\footnotetext{
${ }^{1}$ The paper has been published bilangually, the German version:“",Ich säe was, was Du nicht säst”- Die Wirtschaftlichkeit des Gemengeanbaus von Winterackerbohne und Winterweizen " is included in the Appendix
} 
included the mixed cropping with winter faba bean and winter wheat as a production alternative was developed and optimized using a linear programming approach. Applying a sensitivity analysis to the model enabled the identification critical values for the gross margin of the mixed stand with winter faba bean and winter wheat that have to be reached, in order for the mixed stand to be included into the economically optimized production program. The paper is the first that uses a whole-farm model in the context of mixed cropping and can therefore give valuable implications for policy makers about the extent that financial incentives might be needed to facilitate the adoption of mixed cropping in Germany.

Linking to the content of Chapter 3, the paper titled "Will Farmers Accept Lower Gross Margins for the Sustainable Cultivation Method of Mixed Cropping? First Insights from Germany" (published in Sustainability) presented in Chapter 4 focuses on the farmers' view on the profitability of mixed cropping. There is consensus in the literature that adoption of mixed cropping across Europe could be facilitated by the implementation of an environmental scheme (Bedoussac et al. 2015; Mamine and Farès 2020). The evaluation of farmers' willingness to accept (WTA) profitability changes is a step towards assessing the extent to which financial incentives are necessary. Especially considering the many associated challenges that have been identified, like technical barriers and difficulties in crop protection (Jensen et al. 2020; Mamine and Farès 2020), the adoption of mixed cropping is also associated with a higher risk from the farmers' perspective. Several studies have shown that farmers are heterogeneous with respect to their WTA payments for ecosystem services and that farmers are not behaving in a strictly profit maximizing way (Buckley et al. 2012; Chouinard et al. 2008; Da Motta and Ortiz 2018; Marr and Howley 2019). If the objective is to establish mixed cropping as a cultivation method within the production portfolio of farms in the long-run, it is hence also essential to get an understanding whether farmers evaluation of the profitability levels mixed cropping needs to reach are heterogeneous. Therefore, the research questions addressed in this chapter are:

(1) Are farmers willing to forgo profits for the cultivation method of mixed cropping?

(2) Do farmers' risk attitude and their perception of risks associated with mixed cropping influence the willingness to accept profitability changes? 
Based on a sample of 134 German farmers who are non-adopters of mixed cropping, this paper utilizes a stated preference approach to assess the farmers WTA gross margin reductions. Choosing the gross margin of the cereal as the benchmark, the non-adopters could be classified into three distinct groups: Farmers not willing to accept an equal gross margin, Farmers willing to accept an equal gross margin, and farmers willing to accept a gross margin reduction in the mixed stand compared to the pure cereal stand. An ordered logit model was estimated to analyze the influence of the farmers risk attitude, based on the scale developed by Dohmen et al. (2011), their perception of risk associated with mixed cropping, sociodemographic, and farm related variables on the WTA.

Chapter 5 contains the last paper included in this cumulative thesis, which represents a partial content excursion. While Chapters 2 to 4 focus on mixed cropping with main crops, as a specific cultivation method within the agricultural crop production, Chapter 5 takes broader perspective on crop production. The paper "Understanding the Adoption of Smartphone Apps in Crops Protection" (published in Precision Agriculture) focuses on farmers' intention to and use of smartphone apps as a decision support tool (DST) for crop protection.

To reduce negative externalities through chemical crop protection, the EU has implemented regulations for integrated pest management (European Union 2009). Facing increasingly stricter legal regulations, crop protection becomes ever more challenging for farmers as the management requirements increase. New technologies, like smartphones, can simplify the provision of and access to information as they enable knowledge transfer in the form of practical recommendations to the farmers. These so called DST can for instance be used to identify plant diseases (Hallau et al. 2018), to simulate the disease development (Damos 2015), and to optimize pesticide applications (Nansen et al. 2015). Smartphone based apps have emerged as the most recent category of these DST and can be viewed as a part of precision agriculture technologies. The inherent possibility to use smartphones mobile, even in the field, makes them of particular interest for the agricultural sector as they fit well within the work routine of farmers and do not require large investments. The computational power of smartphones has massively increased recently and the build-in sensors offer numerous functions that can also be used for DST with respect to crop protection (Pongnumkul et al. 2015). Crop protection apps can therefore contribute 
to reducing negative environmental effects and supporting integrated pest management decisions by farmers. However, the adoption of smartphone apps for agricultural production lags behind its expected uptake (Hoffmann et al. 2014).

To gain a deeper understanding of the farmers' adoption and usage decision related to crop protection apps, the presented paper applies the Unified Theory of Acceptance and Use of Technology (UTAUT) which was introduced by Venkatesh et al. (2003). The UTAUT combines aspects of eight different theories, inter alia the TPB (Ajzen 1985) and the Technology Acceptance Model (TAM) (Davis 1989). The theory postulates that the "Behavioral Intention to Use" is driven by the "Performance Expectancy", the "Effort Expectancy", the "Social Influence", and the "Facilitating Conditions", which in turn influences the "Behavior". Poor on-farm performance and a mismatch between the expectations of developers and farmers, as the end users, have been named as reasons the implementation of these DST has been low (Lindblom et al. 2017; Rose et al. 2016). It has been repeatedly emphasized in the literature that the targeted end-users, i.e., the farmers, should be involved in the development process, to make sure that these tools meet their demands and will consequently be used (Inwood and Dale 2019; Rose et al. 2016; Rose et al. 2018). Bonke et al. (2018) have shown that a majority of German farmers are generally willing to pay for crop protection apps and which types of apps they perceive as useful. They did however not analyze the adoption decision itself. The presented paper therefore adds to the literature by answering the following research questions:

(1) Which underlying psychological factors influence farmers' intention to use crop protection apps using the UTAUT?

(2) What types of crop protection app functions do famers view as useful and which do they actually use?

Based on a sample of 207 German farmers, this paper applies the UTAUT to the adoption of crop protection apps. The econometric estimations consist of a PLS-SEM (Hair et al. 2017) and a logit model. With respect to the second research question, the paper contrasts which individual crop protection app features farmers perceive as useful and which they actually use. This comparison allows for a direct detection of areas, in which there is mismatch between the end users demands and what the market supplies. 
In the following chapters, the four papers are presented subsequently. The first three papers answer the outlined research questions about the behavioral and economic aspects associated with the adoption of mixed cropping with main crops. The last paper addresses the research questions related to the use of crop protection apps. In Chapter 6 the results of the individual papers are summarized and their policy implications discussed. 


\section{References}

Ajzen I (1985) From Intentions to Actions: A Theory of Planned Behavior. In: Kuhl J, Beckmann J (eds) Action control: From cognition to behavior, 1st edn., vol 34. Springer, Berlin, 11-39. https://doi.org/10.1007/978-3-642-69746-3_2

Ajzen I (1991) The Theory of Planned Behavior. Organizational Behavior and Human Decision Processes 50(2): 179-211.

Andrews DJ, Kassam AH (1976): The Importance of Multiple Cropping in Increasing World Food Supplies. In: Multiple Cropping, vol 27. John Wiley \& Sons, Ltd, 1-10.

Bedoussac L, Justes E (2010) The efficiency of a durum wheat-winter pea intercrop to improve yield and wheat grain protein concentration depends on $\mathrm{N}$ availability during early growth. Plant Soil 330:19-35. https://doi.org/10.1007/s11104-009-0082-2

Bedoussac L, Journet E-P, Hauggaard-Nielsen H, Naudin C, Corre-Hellou G, Jensen ES, Prieur L, Justes E (2015) Ecological principles underlying the increase of productivity achieved by cereal-grain legume intercrops in organic farming. A review. Agron. Sustain. Dev. 35:911-935. https://doi.org/10.1007/s13593-014-0277-7

Bonke V, Fecke W, Michels M, Musshoff O (2018) Willingness to pay for smartphone apps facilitating sustainable crop protection. Agron. Sustain. Dev. 38:1-10. https://doi.org/10.1007/s13593-018-0532-4

Buckley C, Hynes S, Mechan S (2012) Supply of an ecosystem service-Farmers' willingness to adopt riparian buffer zones in agricultural catchments. Environ. Science $\mathcal{E}$ Policy 24:101-109. https://doi.org/10.1016/j.envsci.2012.07.022

Chen G, Kong X, Gan Y, Zhang R, Feng F, Yu A, Zhao C, Wan S, Chai Q (2018) Enhancing the sys-tems productivity and water use efficiency through coordinated soil water sharing and com-pensation in strip-intercropping. Sci. Rep. 8:1-11. https://doi.org/10.1038/s41598-018-28612-6

Chouinard HH, Paterson T, Wandschneider PR, Ohler AM (2008) Will Farmers Trade Profits for Stewardship? Heterogeneous Motivations for Farm Practice Selection. Land Econ. 84:66-82. https://doi.org/10.3368/le.84.1.66

Da Motta RS, Ortiz RA (2018) Costs and Perceptions Conditioning Willingness to Accept Payments for Ecosystem Services in a Brazilian Case. Ecol.Econ. 147:333-342. https://doi.org/10.1016/j.ecolecon.2018.01.032

Damos P (2015) Modular structure of web-based decision support systems for integrated pest man-agement. A review. Agron. Sustain. Dev. 35:1347-1372. https://doi.org/10.1007/s13593-015-0319-9

Davis FD (1989) Perceived Usefulness, Perceived Ease of Use, and User Acceptance of Information Technology. MIS Quarterly 13:319. https://doi.org/10.2307/249008

Dessart FJ, Barreiro-Hurlé J, van Bavel R (2019) Behavioural factors affecting the adoption of sus-tainable farming practices: a policy-oriented review. Europ. Rev. Agri. Econ. 46:417-471. https://doi.org/10.1093/erae/jbz019 
Dohmen T, Falk A, Huffman D, Sunde U, Schupp J, Wagner GG (2011) Individual Risk Attitudes: Measurement, Determinants, and Behavioral Consequences. J. Euro. Econ. Assoc. 9:522-550. https://doi.org/10.1111/j.1542-4774.2011.01015.x

Ergon Å, Kirwan L, Bleken MA, Skjelvåg AO, Collins RP, Rognli OA (2016) Species interactions in a grassland mixture under low nitrogen fertilization and two cutting frequencies: 1. dry-matter yield and dynamics of species composition. Grass Forage Sci. 71:667-682. https://doi.org/10.1111/gfs.12250

Eurpoean Union (2009) Directive 2009/128/EC of the European Parliament and of the Council of 21 October 2009 establishing a framework for Community action to achieve sustainable use of pesticides.

EUROSTAT (2020a) Agricultral Production - crops. https://ec.europa.eu/eurostat/statisticsexplained/index.php?title=Agricultural_production_-_crops\#Cereals . Last accessed 26 Januar 2021

EUROSTAT (2020b) Agri-environmental indicator - mineral fertiliser consumption. https://ec.europa.eu/eurostat/statistics-explained/index.php?title=Agri-environmental_indicator_-_mineral_fertiliser_consumption. Last accessed 26 Januar 2021

FAOSTAT (2020) Production.Crops. http://www.fao.org/faostat/en/\#data/QC. Last accessed 2 Feburary 2020

Gaba S, Lescourret F, Boudsocq S, Enjalbert J, Hinsinger P, Journet E-P, et al. (2015) Multiple cropping systems as drivers for providing multiple ecosystem services: from concepts to design. Agron. Sustain. Dev. 35:607-623. https://doi.org/10.1007/s13593-0140272-z

Gellings CW, Parmenter KE (2016) Energy efficiency in fertilizer production and use. Efficient Use and Conservation of Energy, In: Gellings, CW (ed): Encyclopedia of Life Support Systems, 123-136.

Greiner R (2015) Motivations and attitudes influence farmers' willingness to participate in biodiver-sity conservation contracts. Agricultural Systems 137:154-165. https://doi.org/10.1016/j.agsy.2015.04.005

Hair JF, Hult GTM, Ringle CM, Sarstedt M (2017) A primer on partial least squares structural equa-tion modeling (PLS-SEM). SAGE, Los Angeles, London, New Delhi, Singapore, Washington DC, Melbourne.

Hallau L, Neumann M, Klatt B, Kleinhenz B, Klein T, Kuhn C, Röhrig M, Bauckhage C, Kersting K, Mahlein A-K, Steiner U, Oerke E-C (2018) Automated identification of sugar beet diseases using smartphones. Plant Pathology 67:399-410. https://doi.org/10.1111/ppa.12741

Hauggaard-Nielsen H, Ambus P, Jensen ES (2003) The comparison of nitrogen use and leaching in sole cropped versus intercropped pea and barley. Nutr. Cycl. Agroecosystems 65:289-300. https://doi.org/10.1023/A:1022612528161

Hauggaard-Nielsen H, Jørnsgaard B, Kinane J, Jensen ES (2008) Grain legume-cereal intercropping: The practical application of diversity, competition and facilitation in arable 
and organic crop-ping systems. Renew. Agric. Food Syst. 23:3-12.

https://doi.org/10.1017/S1742170507002025

Hof C, Rauber R (2003) Anbau von Gemengen im ökologischen Landbau. Institut für Pflanzenbau und Pflanzenzüchtung, Georg-August-Universität Göttingen, Göttingen. https://biokulturorg.files.wordpress.com/2017/11/anbau-von-gemengen-im-c3b6kologischen-landbau.pdf

Hoffmann C, Askari AA, Hoang K, Doluschitz R (2014) Entwicklungstrends bei landwirtschaftlichen Applikationen - ein Zwischenfazit. Landtechnik 69:250-255. https://doi.org/10.15150/1t.2014.618

Inwood SEE, Dale VH (2019) State of apps targeting management for sustainability of agricultural landscapes. A review. Agron. Sustain. Dev. 39:1-15. https://doi.org/10.1007/s13593-018-0549-8

Jensen ES, Carlsson G, Hauggaard-Nielsen H (2020) Intercropping of grain legumes and cereals improves the use of soil $\mathrm{N}$ resources and reduces the requirement for synthetic fertilizer N: A global-scale analysis. Agron. Sustain. Dev. 40:1-9. https://doi.org/10.1007/s13593-020-0607-x

Labeyrie V, Antona M, Baudry J, Bazile D, Bodin Ö, Caillon S, Leclerc C, Le Page C, Louafi S, Mariel J, Massol F, Thomas M (2021) Networking agrobiodiversity management to foster biodiversity-based agriculture. A review. Agron. Sustain. Dev. 41:1-15. https://doi.org/10.1007/s13593-020-00662-z

Lemken D, Spiller A, Meyer-Höfer M von (2017) The Case of Legume-Cereal Crop Mixtures in Modern Agriculture and the Transtheoretical Model of Gradual Adoption. Ecol. Econ. 137:20-28. https://doi.org/10.1016/j.ecolecon.2017.02.021

Lindblom J, Lundström C, Ljung M, Jonsson A (2017) Promoting sustainable intensification in pre-cision agriculture: review of decision support systems development and strategies. Precision Agric. 18:309-331. https://doi.org/10.1007/s11119-016-9491-4

Lithourgidis AS, Dordas CA, Damalas CA, Vlachostergios DN (2011) Annual intercrops: an alternative pathway for sustainable agriculture. Australian J. Crop Sci. 5(4):396-410.

Lokhorst AM, Staats H, van Dijk J, van Dijk E, Snoo G de (2011) What's in it for Me? Motivational Differences between Farmers' Subsidised and Non-Subsidised Conservation Practices. Appl. Psychology 60:337-353. https://doi.org/10.1111/j.1464-0597.2011.00438.x

Mamine F, Farès M'h (2020) Barriers and Levers to Developing Wheat-Pea Intercropping in Europe: A Review. Sustainability 12:6962. https://doi.org/10.3390/su12176962

Marr EJ, Howley P (2019) The accidental environmentalists: Factors affecting farmers' adoption of pro-environmental activities in England and Ontario. J. Rur. Stud. 68:100111. https://doi.org/10.1016/j.jrurstud.2019.01.013

Mawois M, Vidal A, Revoyron E, Casagrande M, Jeuffroy M-H, Le Bail M (2019) Transition to legume-based farming systems requires stable outlets, learning, and peer-networking. Agron. Sustain. Dev. 39:19. https://doi.org/10.1007/s13593-019-0559-1 
Melchior IC, Newig J (2021) Governing Transitions towards Sustainable Agriculture-Taking Stock of an Emerging Field of Research. Sustainability 13:528. https://doi.org/10.3390/su13020528

Meynard J-M, Charrier F, Fares M'h, Le Bail M, Magrini M-B, Charlier A, Messéan A (2018) Socio-technical lock-in hinders crop diversification in France. Agron. Sustain. Dev. 38:116. https://doi.org/10.1007/s13593-018-0535-1

Mills J, Gaskell P, Ingram J, Dwyer J, Reed M, Short C (2017) Engaging farmers in environmental management through a better understanding of behaviour. Agric. Hum. Values 34:283-299. https://doi.org/10.1007/s10460-016-9705-4

Nansen C, Ferguson JC, Moore J, Groves L, Emery R, Garel N, Hewitt A (2015) Optimizing pesticide spray coverage using a novel web and smartphone tool, SnapCard. Agron. Sustain. Dev. 35:1075-1085. https://doi.org/10.1007/s13593-015-0309-y

Ofori F, Stern WR (1987) Cereal-Legume Intercropping Systems. Advances in Agro. 41:4190. https://doi.org/10.1016/S0065-2113(08)60802-0

Peoples MB, Brockwell J, Herridge DF, Rochester IJ, Alves BJR, Urquiaga S, Boddey RM, Dakora FD, Bhattarai S, Maskey SL, Sampet C, Rerkasem B, Khan DF, HauggaardNielsen H, Jensen ES (2009) The contributions of nitrogen-fixing crop legumes to the productivity of agricultural systems. Symbiosis 48:1-17. https://doi.org/10.1007/BF03179980

Pongnumkul S, Chaovalit P, Surasvadi N (2015) Applications of Smartphone-Based Sensors in Ag-riculture: A Systematic Review of Research. J. Sensors 2015. https://doi.org/10.1155/2015/195308

Postma JA, Lynch JP (2012) Complementarity in root architecture for nutrient uptake in ancient maize/bean and maize/bean/squash polycultures. Ann. Bot. 110:521-534. https://doi.org/10.1093/aob/mcs082

Raseduzzaman M, Jensen ES (2017) Does intercropping enhance yield stability in arable crop pro-duction? A meta-analysis. Euro. J. Agron. 91:25-33. https://doi.org/10.1016/j.eja.2017.09.009

Rodriguez C, Carlsson G, Englund J-E, Flöhr A, Pelzer E, Jeuffroy M-H, Makowski D, Jensen ES (2020) Grain legume-cereal intercropping enhances the use of soil-derived and biologically fixed nitrogen in temperate agroecosystems. A meta-analysis. Euro. J. Agron. 118:126077. https://doi.org/10.1016/j.eja.2020.126077

Rosa-Schleich J, Loos J, Mußhoff O, Tscharntke T (2019) Ecological-economic trade-offs of Diversified Farming Systems - A review. Ecol. Econ. 160:251-263. https://doi.org/10.1016/j.ecolecon.2019.03.002

Rose DC, Sutherland WJ, Parker C, Lobley M, Winter M, Morris C, Twining S, Ffoulkes C, Amano T, Dicks LV (2016) Decision support tools for agriculture: towards effective design and delivery. Agricultural Systems 149:165-174. https://doi.org/10.1016/j.agsy.2016.09.009 
Rose DC, Parker C, Fodey J, Park C, Sutherland W, Dicks L (2018) Involving stakeholders in agricultural decision support systems: Improving user-centred design. Intern. J. Agri. Manag. 6(3-4), 80-89.

Siebrecht-Schöll D (2019) Züchterische Analyse von acht Winterackerbohnengenotypen für den Gemengeanbau mit Winterweizen. Doctoral Dissertation, Georg-August-Universität, Göttingen

United Nations (2015). Resolution Adopted by the General Assembly on 25 September 2015; Transforming Our World: The 2030 Agenda for Sustainable Development https://www.un.org/en/development/desa/population/migration/generalassembly/docs/globalcompact/A_RES_70_1_E.pdf

van Dijk WFA, Lokhorst AM, Berendse F, Snoo GR de (2016) Factors underlying farmers' intentions to perform unsubsidised agri-environmental measures. Land Use Policy 59:207-216. https://doi.org/10.1016/j.landusepol.2016.09.003

Vandermeer JH (1992) The ecology of intercropping. Cambridge University Press, Cambridge, New York, Melbourne

Venkatesh, Morris, Davis (2003) User Acceptance of Information Technology: Toward a Unified View. MIS Quarterly 27:425. https://doi.org/10.2307/30036540

Wezel A, Casagrande M, Celette F, Vian J-F, Ferrer A, Peigné J (2014) Agroecological practices for sustainable agriculture. A review. Agron. Sustain. Dev. 34:1-20. https://doi.org/10.1007/s13593-013-0180-7

Zander P, Amjath-Babu TS, Preissel S, Reckling M, Bues A, Schläfke N, Kuhlman T, Bachinger J, Uthes S, Stoddard F, Murphy-Bokern D, Watson C (2016) Grain legume decline and potential recovery in European agriculture: a review. Agron. Sustain. Dev. 36:1-20. https://doi.org/10.1007/s13593-016-0365-y

Zhang F, Li L (2003) Using competitive and facilitative interactions in intercropping systems en-hances crop productivity and nutrient-use efficiency. Plant and Soil 248:305312. https://doi.org/10.1023/A:1022352229863

Zimmer S, Liebe U, Didier J-P, Heß J (2016) Luxembourgish farmers' lack of information about grain legume cultivation. Agron. Sustain. Dev. 36:911. https://doi.org/10.1007/s13593-015-0339-5 


\title{
2. Understanding German Farmer's Intention to Adopt Mixed Cropping using the Theory of Planned Behavior
}

\author{
Vanessa Bonke and Oliver Musshoff
}

Published in: Agronomy for Sustainable Development, 2020, 40(48):1-14;

https://doi.org/10.1007/s13593-020-00653-0

\begin{abstract}
The diversification of cropping systems has the potential to contribute towards a sustainable land use while preserving biodiversity. Mixed cropping is one possibility to increase biodiversity within farming systems. However, adoption of mixed cropping systems is challenging for farmers, as the agricultural sector has evolved around pure stands over the past decades and path dependencies have emerged. Yet, little is known about farmers' motivation to adopt mixed cropping. Utilizing the Theory of Planned Behavior as the main framework, this paper studies the psychological factors underlying farmers' intention to adopt mixed cropping based on an online survey with 172 German farmers. In addition, the most crucial adoption obstacles are assessed. Using partial least squares structural equation modeling, we show for the first time that attitude, perceived behavioral control and injunctive as well as descriptive group norms explain over $52 \%$ of farmers' intention to adopt mixed cropping. Our results also demonstrate that perceived ecological benefits positively influence a farmer's attitude towards mixed cropping. Missing sales opportunities for mixed yields, the uneven maturing of crops and deficient economic benefits are ranked as the most crucial obstacles for the implementation of mixed cropping. These results, which can be relevant for other European countries as well, indicate that the introduction of a voluntary agri-environmental scheme could encourage adoption and that considering positive effects of group norms within policy schemes could further increase adoption on a large scale.
\end{abstract}

Keywords: mixed cropping adoption, Theory of Planned Behavior, partial least squares structural equation modeling, logit model 


\title{
3. The Profitability of Mixed Cropping with Winter Faba Bean and Winter Wheat
}

\author{
Vanessa Bonke, Daniel Siebrecht-Schöll and Oliver Musshoff
}

Published in: Berichte über Landwirtschaft - Zeitschrift für Landwirtschaft und Agrarpolitik, 2021, 99(3):1-33;

https://doi.org/10.12767/buel.v99i2.387

The German version is included in the Appendix of the thesis.

\begin{abstract}
One possibility to increase the biodiversity in German agriculture is mixed cropping. The simultaneous cultivation of legumes and non-legumes can inter alia help to save synthetic nitrogen fertilizers. However, this form of cultivation is currently not widespread in Germany and the availability of information is low from a practical point of view. In particular, only very limited information about the economic efficiency of different mixed cropping combinations is available. Against this background, this paper evaluates the profitability of mixed stands using the example of winter faba bean and winter wheat based on the results of a field trial. The results indicate that mixed cropping with winter faba bean and winter wheat in the implemented form is currently not economically competitive in conventional German agriculture. However, mixed cropping in the present form seems to be suitable especially for sites with poorer site characteristics. The results of the sensitivity analysis of a whole-farm optimization model show that the gross margins of the mixed stands would even have to surpass that of the dominantly produced cereals in pure stand.
\end{abstract}




\title{
4. Will Farmers Accept Lower Gross Margins for the Sustainable Cultivation Method of Mixed Cropping? First Insights from Germany
}

\author{
Vanessa Bonke, Marius Michels and Oliver Musshoff
}

Published in: Sustainability, 2021, 13(4), 1631: 1-14;

https://doi.org/10.3390/su13041631

\begin{abstract}
A decline in the legume cultivation has contributed to the biodiversity loss within the agricultural production across Europe. One possibility to include legumes into the production and promote sustainability is mixed cropping with legumes and non-legumes. However, the adoption of mixed cropping is challenging for farmers and information about the profitability is scarce. If mixed cropping should become a widely established production method, it is essential to gain an understanding of famers' evaluation of the profitability mixed cropping needs to reach. Therefore, this article provides first empirical insights into farmers stated willingness to accept gross margin changes compared to current production possibilities. Based on a survey with results from 134 German non-adopters conducted in 2018 we can distinguish conventional farmers with a positive, neutral and negative willingness to accept reductions in gross margins as the trade-off for ecological benefits. Using an ordered logistic model, we find that risk attitude, risk perception, the number of measures performed for ecological focus areas, the farmer's age and being located in the south of Germany influence their willingness to accept gross margin changes compared to currently produced cereals.
\end{abstract}

Keywords: willingness to accept, gross margin, mixed cropping, ordered logit regression 


\title{
5. Understanding the Adoption of Smartphone Apps in Crop Protection
}

\author{
Marius Michels, Vanessa Bonke and Oliver Musshoff \\ A similar version is published in: Precision Agriculture, 2020, 21:1209-1226; \\ https://doi.org/10.1007/s11119-020-09715-5
}

\begin{abstract}
There is a steady increase in smartphone apps available to improve farmers' decision making with respect to crop protection. While current studies have focused on smartphone adoption in general and farmers' general willingness to pay for crop protection smartphone apps, none have focused on the initial adoption decision. Furthermore, it has not been studied yet which app functions are perceived as useful and which are actually used by farmers. Based on an online survey conducted in 2019 with 207 German farmers, this study investigated latent factors affecting farmers' adoption decision for crop protection smartphone apps based on the Unified Theory of Acceptance and Use of Technology (UTAUT) framework applying partial least squares equation modeling and a binary logit model. Descriptive results show that $95 \%$ of the surveyed farmers use a smartphone, but only $71 \%$ use a crop protection smartphone app. Apps providing information about weather, pest scouting and infestations forecasts are perceived as most useful by the majority of farmers. However, reported use fell short of reported usefulness. With respect to the model for the UTAUT, 73 $\%$ of the variation in the behavioral intention to use a crop protection smartphone app and $50 \%$ of the variation in the actual adoption is explained by the model. The results are of interest for policy makers in the field of digitization in agriculture as well as providers and developers of crop protection smartphone apps since the results could be used for further development of apps and policies regarding digitization.
\end{abstract}

Keywords: crop protection, digitization, smartphone, smartphone apps, Unified Theory of Acceptance and Use of Technology 


\section{Summary and Conclusion}

The first three papers of this thesis study the behavioral and economic aspects associated with farmers' adoption of mixed cropping with legumes and non-legumes. The first paper focuses on the psychological factors influencing the acceptance of mixed cropping by farmers and on assessing the adoption obstacles based on survey data. The second paper uses yield data from field experiments to evaluate the profitability of mixed cropping on the farm level. The third paper addresses the farmers' willingness to accept profitability changes for the implementation of mixed cropping. As an excursus, the last paper studies the use of smartphone crop protection apps. In the following, the results and conclusions are summarized for the individual papers consecutively. Additionally, political implications are provided and potential starting points for future research are given.

The first paper presented in Chapter 2 had two main objectives: studying the psychological factors underlying the farmers' behavior and assessing obstacles to the adoption of mixed cropping from a practical point of view. To analyze the behavioral drivers of farmers' intention to adopt mixed cropping based on a sample of 172 German farmers, an extended version of the Theory of Planned Behavior (TPB) (Ajzen 1985) was used. The constructs "Injunctive Group Norm" and "Descriptive Group Norm" which originate in social identity theory were added, as well as a construct for the "Perceived Ecological Benefits". The results of the Partial Least Squares Structural Equation Model show that the applied theory explains over 52\% of the farmer's intention to adopt mixed cropping. Among the psychological factors included, the "Attitude towards mixed cropping" has the strongest effect on the "Intention", which in turn is a strong indicator for the actual adoption as the estimated logit models show. Within the sample, $13 \%$ of farmers have already adopted mixed cropping with main crops. In contrast to the original TPB, the model shows a slightly, statistically non-significant, negative effect of "Subjective Norm", which was conceptualized as social pressure from politics and society. Whereas, the social group norms statistically significantly positively influence farmer's intention to adopt mixed cropping. These results jointly suggest that the farmers' willingness to adopt is a strong predictor for the actual adoption decision and that one lever to increase their willingness is to utilize positive effects of social group norms. This also 
emphasizes the relevance of including farmers as early as possible into current research efforts, in order to encourage early adoption and the associated increased awareness of mixed cropping among farmers. Promoting an improved knowledge transfer between scientists and practitioners as well as between early adopters and non-adopters of mixed cropping can enhance the adoption process. The results further imply that it would be beneficial to include mixed cropping into voluntary agrienvironmental schemes on national levels to encourage adoption, but implementing mandatory restrictions could also have the opposite effect and result in reactance (Miron and Brehm 2006). Utilizing the positive effects of group norms within a policy scheme could further enhance adoption. For the "Perceived Ecological Benefits", the results indicate that only the indirect effect via the "Attitude" towards "Intention" is statistically significant, but not the direct effect of "Perceived Ecological Benefits" on "Intention". This suggests an indirect-only mediation (Hair et al. 2017; Zhao et al. 2010), i.e. "Ecological Benefits" lead to a higher "Attitude" which in turn leads to a higher "Intention". It implies that farmers do value more sustainable practices and that practice characteristics are relevant in the decision making process of farmers, but only indirect. Overall, the results of the TPB emphasize the pertinence of psychological factors for the intention to adopt mixed cropping, indicating that the adoption of this sustainable practice is not solely dependent on economic reasoning and that the willingness to adopt is especially relevant for this case.

Nevertheless, as the assessed obstacles indicate, insufficient economic benefits are a major barrier that hinders widespread adoption by German farmers, which supports the relevance of an agri-environmental scheme to increase adoption of mixed cropping. Missing sales opportunities for mixed yields were ranked as the most important obstacles both from adopters and non-adopters. Processing firms are currently not adapted to the separation of mixed yields; the separation is an additional processing step which is also associated with higher costs. If farmers cannot easily market the yields, transaction costs will be higher compared to their pure stand yields or the farmers are faced with an additional workload by separating the yield themselves. With respect to the marketing of the legumes from a mixed stand for human consumption another issue can arise, if it is not possible to completely separate the cereal in the processing steps. For instance, consumers might choose a legume based pasta due to food intolerances such as gluten intolerance. If the legume based pasta contains traces of wheat, due to the cultivation as a mixed stand, the 
pasta would not be suited for consumers with food intolerances which would reduce the number of customers and thus the potential market share for the processing firms. The uneven maturing of crops is also among the top obstacles from the farmers' point of view. This emphasizes the need for the breeding of varieties that are adapted to mixed cropping cultivation. Or, in cases where suitable varieties exist, a better communication between plant breeders, advisers, and farmers. Difficulties in crop protection and technical barriers are also among the high ranking obstacles. Here the ongoing progress in precision agriculture technologies might reduce the barriers. For instance, the problem with chemical crop protection in mixed stands is that an application that is beneficial for the one species can be damaging for the other species in the mixed stand. At the present time, there are also no chemical crop protection products for mixed stands approved in Germany for the post-emergence state. Progress in the site- and potentially plant-specific application of crop protection products within the arable fields through precision technologies, could solve this issue. Currently however, the non-applicability of chemical crop protection products increases the cultivation risk. Noticeably, among the adopters of mixed cropping the insufficient knowledge about cultivation and missing advice by experts is ranked comparatively high, whereas these are not among the top obstacles for the non-adopters. This might be due to the fact some challenges become even more apparent after adoption took place and the farmers have already invested more time in gathering information about mixed cropping. The results show which challenges along the value chain, from plant breeding to the processing firms, are perceived as most crucial by farmers in Germany with respect to mixed cropping and therefore should be addressed as such.

Against the background that there is only limited scientific and practical literature on the profitability of mixed stands, the second paper included in this thesis (Chapter 3/Appendix) focuses on the economic evaluation of mixed cropping on a farmlevel basis. Using yield results from the scientific field experiments conducted within the IMPAC ${ }^{3}$ project in Göttingen, gross margins and the relative gross margins of mixtures were calculated for the production of the mixed stands with winter faba bean and winter wheat. Comparing the gross margins of the mixed stand with their corresponding pure stands individually shows that for the high yielding site Reinshof, the unfertilized pure stand of a winter wheat has the highest gross margin in two out of three years among all combinations. The overyielding of the mixed 
stand (Siebrecht-Schöll 2019) due to its complementary use of growth factors and the fixated atmospheric nitrogen cannot compensate for the higher costs associated with the mixed stands, mainly caused by the separation of the mixed yield (approximated with $1.43 € / \mathrm{dt}$ ). And that even though higher prices for the wheat in the mixed stand are used, based on the higher availability of nitrogen in the mixed stand which is supposed to increase to protein content and thus quality. The results for the marginal yielding site Deppoldshausen differ from that. For this location, a mixed stand has the highest gross margin in two out of three years. This can also be seen with the so called "relative gross margins of the mixtures". The index "relative gross margin of mixtures" can lead to confusion among economists, as the "normal" gross margins are already used to evaluate the relative competitiveness of a production method in agricultural business economics. The application of this relative gross margin of mixtures is restricted to mixed cropping and originates from different indices used in the crop science literature, like the Land Equivalent Ratio or the Relative Yield Total (Hof and Rauber 2003). The aim of these indices is to evaluate the "mixing effect" that supposedly leads to overyielding in the mixed stand. They therefore put the mixed stand in proportion to its two corresponding pure stands simultaneously. The relative gross margin of mixture hence answers the question whether cultivating 1 ha of the mixed stand is economically advantageous over cultivating 0.5 ha of each of the two pure stands. For a farmer this index is only relevant when he or she cultivates both the legume and the non-legume already. Since these comparisons are mostly related to the unfertilized pure stands, as it is the case in the present paper, from a practical point of view the relevance of these results is limited. Without any political restrictions or financial incentives in place, the relevant benchmark for farmers are the yields and gross margins of the pure stands produced under practical conditions which usually implies nitrogen fertilizers are applied in cereal crops, either synthetic or organic.

The implemented whole-farm model which was optimized using a linear programming approach, therefore delivers additional implications which reach beyond the calculated gross margins based on the field experiments. On the one hand, interdependencies that arise from the competition of different production methods about fixed production factors within a farm could be considered. On the other hand, a sensitivity analysis of the model with respect to changes in the gross margins of the mixed stand allowed the derivation of critical values that lead to an inclusion of the 
mixed stand in the optimized production program in the sense of a "what-wouldbe-if"-analysis. The results of the first scenario, considering the politically implemented greening restrictions valid in 2016, show that the gross margin of the mixed stand of winter faba bean and winter wheat would need to be about $25 \%$ higher than that of the pure winter wheat ( $727 € /$ ha vs. $583 € /$ ha) to be cultivated on $16 \%$ of the farms arable land. The second scenario considers the changes that have been made to the restrictions for Ecological Focus Areas (EFA) in 2018, in particular it was assumed that the mixed stand can contribute in fulfilling this restriction with a weighting factor of 1 . In this scenario, about $1 \%$ of the arable land would be cultivated with the mixed stand if the gross margin would reach $474 € / \mathrm{ha}$, a further increase in the cultivated area would however still only happen if the gross margins of the mixed stand raises considerably over that of the pure winter wheat. On the one hand, this is due to the fact that the mixed stand directly competes with the pure winter wheat stand in the crop rotation restrictions. On the other hand, it is also because the working hours in the mixed stand are higher caused by the assumption that the separation of the mixed yield is done by the farmers. The results emphasize that mixed cropping under the considered conditions is not profitable enough to be included in an economically optimized conventional German farm.

The whole-farm model implemented in paper two implicitly assumes that farmers are strictly focused on profit maximization. While it is evident that the generation of profits is and needs to be one of the objectives of farmers, the farmers' utility is not solely dependent on profits. This is where the third paper in this dissertation (Chapter 4) approaches the topic of mixed cropping. The paper addresses the question whether farmers are willing to accept (WTA) lower gross margins for the cultivation of mixed cropping. A stated preference approach conceptualized to study if farmers are WTA gross margin reductions as the trade-off for ecological benefits was used to deliver first insights in this area of research. The study used a sample of 134 German non-adopters of mixed cropping, as these are of particular interest for policy makers and researchers. The applied three step questioning approach allowed the differentiation of three groups of farmers that are heterogeneous in their WTA gross margin reductions for the adoption of mixed cropping, namely those with a "negative", a "neutral" and a "positive" WTA. For the group of farmers with a positive WTA gross margin reductions for the adoption of mixed cropping, which made up about half of the sample (54\%), it was also asked how much of the gross margin they 
would be maximally willing to forgo for mixed cropping compared to the stated reference point of the cereal gross margin. The mean response of the $\mathrm{N}=72$ nonadopters who answered this question was $13 \%$, the median $10 \%$.

The adoption of mixed cropping is also associated with changes in the farmers' income risk, implying that the trade-off between profits and risk is of relevance. How this trade-off is evaluated is partially dependent on the subjective risk attitude of the farmers. While the WTA evaluation based on the gross margins could not implicitly account for changes in the income risk, the effect of the farmers' risk attitude and their perception of the risk associated with the cultivation of mixed stands on the WTA gross margin reductions were analyzed. To analyze group differences with respect to the risk attitude and risk perception, an ordered logistic regression was applied. The model further included as set of objectively measurable farm and farm related variables, allowing for an easy distinction of potential target groups for agrienvironmental schemes. The results show that the farmers' risk attitude, their perception of risks associated with mixed cropping, the number of measures performed for Ecological Focus Areas, the farmer's age and being located in the south of Germany statistically significantly influence their WTA gross margin changes compared to currently produced cereals. This indicates that the trade-off between profitability and risk is at least partially responsible for the demand of a higher profitability in mixed stands. These results provide important first insights about the extent of the financial incentives that would be necessary to facilitate mixed cropping in German agriculture. One lever that will facilitate the acceptance of mixed cropping and reduce profitability requirements is reducing the risk associated with the cultivation. The paper represents a starting point into further research with respect to farmers' willingness to accept payments for the adoption of mixed cropping.

Comprehensively, the first three papers in the thesis allow for relevant implications to be drawn regarding the possibilities of expanding the cultivation of mixed stands in German agriculture. Likewise, each of the studies point to open research questions which should be addressed in the future. Establishing mixed cropping as a regular alternative in the production portfolio of farms will need the involvement of several actors along the value chain. The economic calculations show that the gross margin of the mixed stand would have to increase above that of the cereal pure stand in order to be included into an economically optimized production program. On the counterpart, the farmers' responses show that a group of them would be willing to 
accept a lower gross margin in the mixed stand compared to the cereal pure stand. This group of farmers is a potential target group for an agri-environmental or certification scheme, as these will demand the lowest financial incentives. Nonetheless, the results show that German farmers are willing to adopt mixed cropping and do value ecologically beneficial cultivation methods, but the phrase "it is hard to be green, when you are in the red" (Richards et al. 2005) seems to be applicable for mixed cropping in Germany. The relative competitiveness of mixed cropping has to be increased in order to make it an economically viable option for German farmers. While the presented papers focus on the farmers, the profitability aspects of mixed cropping are also relevant for other actors in the value chain. Plant breeders will not focus on breeding adapted varieties for mixed cropping if there is no potential market to sell these varieties. Likewise, actors in the downstream value chain will not invest in technologies to process mixed yields, if the expected returns are low. Thus, involving stakeholders along the value chain in order to overcome the technological lock-in will be of particular relevance, like Meynard et al. (2018) and Mawois et al. (2019) also emphasize for the legume production.

Future research could for instance use choice experiments to assess possibilities of different agri-environmental or certification schemes to facilitate mixed cropping and elicit WTA values for different options and attributes. Assessing possibilities to reduce risk, for instance by decoupling incentives from the produced marketable output in mixed stands, could be one way to reduce compensation requirements by farmers. The limited availability of practical information is another risk factor that can be addressed. Further, it will be important to reduce ambiguity when it comes the formulation of political or potential certification restrictions, as the communication between different stakeholders can be peculiar for mixed cropping as discussed in Chapter 3.

The fourth and last paper (Chapter 5) included in this thesis diverts from the topic of mixed cropping. While mixed cropping is a specialized production method that can contribute towards a more ecologically beneficial production, multiple possibilities to facilitate sustainability in agriculture exist. Another possibility to reduce negative environmental impacts of agricultural crop production is the application of new technologies. In particular, the presented paper focuses on the use of crop protection smartphone apps as a decision support tool for farmers. Applying the UTAUT (Venkatesh et al. 2003) based on a survey with 207 German farmers, the 
paper studies which behavioral factors influence the decision to use a smartphone crop protection app. The estimated Partial Least Squares Structural Equation Model can explain $73 \%$ of the farmers' intention to use such an app. The effect of "Facilitating Conditions" on the "Behavioral Intention" was very small and not statistically significant, whereas the effect on the "Adoption" is statistically significant in the logit model. This factor was conceptualized with respect to mobile internet coverage and the smartphone capabilities. Since crop protection apps can be assumed to be used in the field, insufficient mobile internet coverage can restrict the number of apps which are usable. For developers this implies that apps should, at least to a certain extent, work without a constant internet connection. However, as apps become more complex and real-time access to databases ever more relevant, this also indicates that policy makers in Germany should encourage advancing the mobile internet coverage in rural areas. An adequate internet connection has also been emphasized as a relevant precondition for other precision agriculture technologies (e.g., Khanna and Kaur 2019).

The paper also evaluates which features of crop protection apps farmers perceive as useful and which they actually use at the same time. A total of $82 \%$ of the farmers were aware of specific crop protection apps, but only $71 \%$ of those owning a smartphone actually use a crop protection app. Apps providing weather information, pest scouting and infestation forecasts, and features that allow the documentation are perceived as useful by a majority of farmers. Therefore, developers and providers should focus on further enhancing and improving these types of apps or app features. However, the results also show that the usage rates of the individual features lag behind their perceived usefulness in many cases. In particular for those cases, there is a chance to develop new or improved apps that will facilitate farmers' decision making. To increase the adoption, the results from the estimated UTAUT model can be utilized. The benefits from using the app must be directly apparent for the farmer when viewing the app in the download store and especially when using it. Possibilities to adjust the app to the specific needs of an individual farmer, e.g. adapted to their cultivated crops, could also increase the adoption. Further research could focus in more detail on how individual app features could be arranged in accordance with the farmers expectations and app layouts be optimized. As Rose et al. (2016) also emphasize involving farmers in the development process will facilitate the use of these technologies. 


\section{References}

Ajzen I (1985) From Intentions to Actions: A Theory of Planned Behavior. In: Kuhl J, Beckmann J (eds) Action control: From cognition to behavior, 1st edn., vol 34. Springer, Berlin, 11-39. https://doi.org/10.1007/978-3-642-69746-3_2

Hair JF, Hult GTM, Ringle CM, Sarstedt M (2017) A primer on partial least squares structural equa-tion modeling (PLS-SEM). SAGE, Los Angeles, London, New Delhi, Singapore, Washington DC, Melbourne.

Hof C, Rauber R (2003) Anbau von Gemengen im ökologischen Landbau. Institut für Pflanzenbau und Pflanzenzüchtung, Georg-August-Universität Göttingen, Göttingen. https://biokulturorg.files.wordpress.com/2017/11/anbau-von-gemengen-im-c3b6kologischen-landbau.pdf

Khanna A, Kaur S (2019) Evolution of Internet of Things (IoT) and its significant impact in the field of Precision Agriculture. Comp.Electr.Agric.157:218-231. https://doi.org/10.1016/j.compag.2018.12.039

Mawois M, Vidal A, Revoyron E, Casagrande M, Jeuffroy M-H, Le Bail M (2019) Transition to legume-based farming systems requires stable outlets, learning, and peer-networking. Agron. Sustain. Dev. 39:19. https://doi.org/10.1007/s13593-019-0559-1

Meynard J-M, Charrier F, Fares M'h, Le Bail M, Magrini M-B, Charlier A, Messéan A (2018) Socio-technical lock-in hinders crop diversification in France. Agron. Sustain. Dev. 38:116. https://doi.org/10.1007/s13593-018-0535-1

Miron AM, Brehm JW (2006) Reactance Theory - 40 Years Later. Zeitschrift für Sozialpsychologie 37:9-18. https://doi.org/10.1024/0044-3514.37.1.9

Richards C, Lawrence G, Kelly N (2005) Beef Production and the Environment: Is it really 'Hard to be Green When You are in the Red'? Rural Society 15:192-209. https://doi.org/10.5172/rsj.351.15.2.192

Rose DC, Sutherland WJ, Parker C, Lobley M, Winter M, Morris C, Twining S, Ffoulkes C, Amano T, Dicks LV (2016) Decision support tools for agriculture: towards effective design and delivery. Agricultural Systems 149:165-174. https://doi.org/10.1016/j.agsy.2016.09.009

Siebrecht-Schöll D (2019) Züchterische Analyse von acht Winterackerbohnengenotypen für den Gemengeanbau mit Winterweizen. Doctoral Dissertation, Georg-August-Universität, Göttingen

Venkatesh, Morris, Davis (2003) User Acceptance of Information Technology: Toward a Unified View. MIS Quarterly 27:425. https://doi.org/10.2307/30036540

Zhao X, Lynch JG, Chen Q (2010) Reconsidering Baron and Kenny: Myths and Truths about Mediation Analysis. J. Cons. Res. 37:197-206. https://doi.org/10.1086/651257 


\title{
Appendix
}

\section{"Ich säe was, was Du nicht säst" \\ - Die Wirtschaftlichkeit des Gemengeanbaus von \\ Winterackerbohne und Winterweizen}

\author{
Vanessa Bonke, Daniel Siebrecht-Schöll und Oliver Musshoff \\ Veröffentlicht in: Berichte über Landwirtschaft - Zeitschrift für Landwirtschaft und Agrar- \\ politik, 2021, 99(2):1-35;
}

https://doi.org/10.12767/buel.v99i2.347

\section{Zusammenfassung}

Eine Möglichkeit, die Biodiversität in der deutschen Landwirtschaft zu erhöhen, ist der Anbau von Gemengen. Der simultane Anbau von Leguminosen und Nicht-Leguminosen kann unter anderem dazu beitragen, synthetische Stickstoffdüngemittel einzusparen. Diese Form des Anbaus ist jedoch derzeit in Deutschland nicht weit verbreitet und die Informationsverfügbarkeit aus praktischer Sicht gering. Insbesondere für die Wirtschaftlichkeit verschiedener Gemengekombinationen sind nur sehr limitiert Informationen verfügbar. Vor diesem Hintergrund bewertet dieser Beitrag die Wirtschaftlichkeit von Gemengen am Beispiel Winterackerbohne und Winterweizen basierend auf den Ergebnissen eines Freilandversuches. Die Ergebnisse deuten darauf hin, dass der Gemengeanbau von Winterackerbohne und Winterweizen in der durchgeführten Form ökonomisch derzeit nicht wettbewerbsfähig in der konventionellen deutschen Landwirtschaft ist. Jedoch scheint der Anbau von Hauptfruchtgemengen eher für Standorte mit schlechteren Standorteigenschaften geeignet zu sein. Die Ergebnisse der Sensitivitätsanalyse eines gesamtbetrieblichen Optimierungsmodells zeigen, dass die Deckungsbeiträge des Gemenges sogar weit über den Deckungsbeitrag der derzeit produzierten Getreidereinsaat steigen müssten, um in den ökonomisch optimierten Beispielbetrieb integriert zu werden. 


\section{Publication List}

\section{Paper Published in Peer-Reviewed Journals}

Bonke, V., Fecke, W., Michels, M. and O. Musshoff (2018): Willingness to pay for smartphone apps facilitating sustainable crop protection. Agronomy for Sustainable Development, 38(5),51:1-10. doi:/10.1007/s13593-018-0532-4

Michels, M., Bonke, V. and O. Musshoff (2019): Understanding the adoption of smartphone apps in dairy herd management. Journal of Dairy Science, 102(10); 9422-9434. doi:/10.3168/jds.2019-16489

Michels, M., Bonke, V. and O. Musshoff (2020): Understanding the adoption of smartphone apps in crop protection. Precision Agriculture, 21:1209-1226. doi:/10.1007/s11119-020-09715-5;

Bonke, V. and O. Musshoff (2020): Understanding German farmer's intention to adopt mixed cropping using the theory of planned behavior. Agronomy for Sustainable Development, 40(48):1-14; doi:/10.1007/s13593-020-00653-0

Bonke, V., Michels, M. and O. Musshoff (2021): Will Farmers Accept Lower Gross Margins for the Sustainable Cultivation Method of Mixed Cropping? First Insights from Germany. Sustainability, 2021, 13(4), 1631:1-14; doi:/10.3390/su13041631

Bonke, V., Siebrecht-Schöll, D. and O. Musshoff (2021): "Ich säe was, was Du nicht säst"- Die Wirtschaftlichkeit des Gemengeanbaus von Winterackerbohne und Winterweizen. Berichte über Landwirtschaft - Zeitschrift für Agrarpolitik und Landwirtschaft, 99(2): 1-35. doi:/10.12767/buel.v99i2.

Bonke, V., Siebrecht-Schöll, D. and O. Musshoff (2021): The Profitability of Mixed Cropping with Winter Faba Bean and Winter Wheat. Berichte über Landwirtschaft - Zeitschrift für Landwirtschaft und Agrarpolitik, 2021, 99(3):1-33; doi:/10.12767/buel.v99i2.387 


\section{Discussion Paper}

Michels, M., Bonke, V. and O. Mußhoff (2019): Understanding the adoption smartphone apps in crop protection - An application of the unified theory of acceptance and use of technology. Diskussionsbeitrag des Departments für Agrarökonomie und Rurale Entwicklung Nr. 1905, Georg-August Universität Göttingen.

\section{Full-Length Conference Paper}

Bonke V. and O. Musshoff (2019): Factors underlying German farmers' intention to adopt mixed cropping. Paper prepared for presentation at the $172^{\text {nd }}$ EAAE Seminar 'Agricultural policy for the environment or environmental policy for agriculture?’ 28-29 Mai, 2019, Brüssel, Belgien.

Michels, M., Bonke, V. and O. Musshoff (2020): Adoption of herd management smartphone apps in German dairy farming. In: Banse et al. (Hrsg.). Landwirtschaft und ländliche Räume im gesellschaftlichen Wandel. Schriften der Gesellschaft für Wirtschafts- und Sozialwissenschaften des Landbaues (GeWiSoLa) e.V., Band 55, Braunschweig. （Best-Paper-Award)

\section{Conference Contributions}

Bonke V. and O. Musshoff (2019): Factors underlying German farmers' intention to adopt mixed cropping. PLANT 2030 Status Seminar, 13-15 März, 2019, Potsdam.

Bonke V. and O. Musshoff (2019): Factors underlying German farmers' intention to adopt mixed cropping. EAAE Seminar 172, organisiert von JRC und DG Agri: "Agricultural policy for the environment or environmental policy for agriculture", 28-29 Mai 2019, Brüssel, Belgien.

Michels, M., Bonke, V., Fecke, W. and O. Musshoff (2019): Sustainability in crop protection - Willingness to pay for crop protection smartphone apps. 29. Jahrestagung der ÖGA, 19-20 September 2019, Innsbruck, Österreich.

(Best-Presentation-Award) 
Michels, M., Bonke, V. and O. Musshoff (2019): Adoption of herd management smartphone apps in German dairy farming. 59. Jahrestagung der GeWiSoLa, 25-27 September 2019, Braunschweig.

Michels, M., Bonke, V. and O. Musshoff (2020): Investigating the adoption of smartphone apps in crop protection. 40te Jahrestagung der Gesellschaft für Informatik in der Land-, Forst-, und Ernährungswirtschaft (GIL), Digitalisierung für Mensch, Umwelt und Tier. 17-18 Februar 2020, Freising.

Michels, M., Bonke, V. and O. Musshoff (2020): Understanding the adoption of crop protection smartphone apps in German agriculture. $15^{\text {th }}$ Biennial Virtual International Conference on Precision Agritulture (VICPA) of the International Society of Precision Agriculture (ISPA). 


\section{Declaration of Contribution}

The table summarizes my contribution to each paper included in this cumulative dissertation. The order of names is determined taking into account of the overall input for each type of contribution.

\section{List of authors by contribution type}

\begin{tabular}{|c|c|c|c|c|}
\hline & Chapter 2 & $\begin{array}{l}\text { Chapter } 3 \\
\text { (Appendix) }\end{array}$ & Chapter 4 & Chapter 5 \\
\hline $\begin{array}{l}\text { Conceptualiza- } \\
\text { tion }\end{array}$ & $\begin{array}{l}\text { V.B. and } \\
\text { O.M. }\end{array}$ & $\begin{array}{l}\text { V.B. and } \\
\text { O.M. }\end{array}$ & $\begin{array}{l}\text { V.B. and } \\
\text { O.M. }\end{array}$ & $\begin{array}{l}\text { M.M., V.B., } \\
\text { O.M. }\end{array}$ \\
\hline Methodology & $\begin{array}{l}\text { V.B. and } \\
\text { O.M. }\end{array}$ & $\begin{array}{l}\text { V.B. and } \\
\text { O.M. }\end{array}$ & $\begin{array}{l}\text { V.B. and } \\
\text { M.M. }\end{array}$ & $\begin{array}{l}\text { M.M., V.B., } \\
\text { O.M. }\end{array}$ \\
\hline $\begin{array}{l}\text { Data collection } \\
\text { and preparation }\end{array}$ & V.B. & D.S.S. & V.B. & $\begin{array}{l}\text { M.M. and } \\
\text { V.B. }\end{array}$ \\
\hline Formal Analysis & V.B. & V.B. & $\begin{array}{l}\text { V.B. and } \\
\text { M.M }\end{array}$ & $\begin{array}{l}\text { M.M. and } \\
\text { V.B. }\end{array}$ \\
\hline Visualization & V.B. & V.B. & V.B. & M.M. \\
\hline $\begin{array}{l}\text { Interpretation of } \\
\text { results }\end{array}$ & $\begin{array}{l}\text { V.B. and } \\
\text { O.M. }\end{array}$ & $\begin{array}{l}\text { V.B., D.S.S, } \\
\text { O.M. }\end{array}$ & $\begin{array}{l}\text { V.B., M.M., } \\
\text { O.M. }\end{array}$ & $\begin{array}{l}\text { M.M., V.B., } \\
\text { O.M. }\end{array}$ \\
\hline $\begin{array}{l}\text { Writing - original } \\
\text { draft preparation }\end{array}$ & $\begin{array}{l}\text { V.B. and } \\
\text { O.M. }\end{array}$ & V.B. & V.B. & $\begin{array}{l}\text { M.M., V.B., } \\
\text { O.M. }\end{array}$ \\
\hline $\begin{array}{l}\text { Writing - Review } \\
\text { and Editing }\end{array}$ & $\begin{array}{l}\text { V.B. and } \\
\text { O.M. }\end{array}$ & $\begin{array}{l}\text { V.B., D.S.S, } \\
\text { O.M. }\end{array}$ & $\begin{array}{l}\text { V.B., M.M., } \\
\text { O.M. }\end{array}$ & $\begin{array}{l}\text { V.B., M.M., } \\
\text { O.M. }\end{array}$ \\
\hline
\end{tabular}

Co-authors:

O.M. - Prof. Dr. Oliver Musshoff

M.M. - Dr. Marius Michels

D.S.S. - Dr. Daniel Siebrecht-Schöll 


\section{Eidesstattliche Erklärungen}

Hiermit erkläre ich eidesstattlich, dass:

1. diese Arbeit weder in gleicher noch in ähnlicher Form bereits anderen Prüfungsbehörden vorgelegen hat.

2. ich mich an keiner anderen Hochschule um einen Doktorgrad beworben habe.

Göttingen, den

(Unterschrift)

Hiermit erkläre ich eidesstattlich, dass diese Dissertation selbständig und ohne unerlaubte Hilfe angefertigt wurde.

Göttingen, den

(Unterschrift) 